\title{
The Impact Of Job Demands And Resources On Job Crafting
}

\author{
Sang-Hoon Lee, University of Illinois at Urbana-Champaign, USA \\ Yuhyung Shin, Hanyang University, Republic of Korea \\ Seung Ik Baek, Hanyang University, Republic of Korea
}

\begin{abstract}
Organizations are constantly under pressure for survival in the current highly volatile work environment. This change has been accelerated by trends such as smart work environments and artificial intelligence in the organizational context. Given such uncertainty deriving from a fast rate of change and high complexity, it is vital for organizations to fully utilize and support individuals to be fully engaged in their work, setting grounds for transformation and modification of general roles and specific tasks. Based on the job demands-resources model, our hypotheses are tested using empirical data extracted from 172 subjects currently working in organizations. By commissioning a questionnaire survey method and hierarchical regression analysis, the results offer partially strong support for our proposed research model. We attained moderate support for our hypotheses, in that an individuals' perception of job resources and job demands in the work context induce job crafting (i.e., task, cognitive, and relational), which acts as a critical mechanism arousing individual work engagement and job stress. In general, job resources (i.e., job autonomy and performance feedback) predicted work engagement, while job demands (i.e., work overload, emotional demands, and technology demands) affected job stress. Also, job demands and job resources both influenced task job crafting, while emotional demands were related to cognitive and relational job crafting, implying different paths between demands and resources and various job crafting activities. In addition, three job crafting dimensions affected work engagement, while only relational job crafting positively affected job stress.
\end{abstract}

Keywords: Job Crafting; Job Demands-Resources Model; Job Demands; Job Resources; Work Engagement; Job Stress

\section{INTRODUCTION}

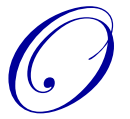

rganizations continuously strive to gain competitiveness, and the role of individuals is a crucial factor in achieving such goals. Traditionally, firms have applied a top-down approach regarding job design, applying methods as suggested by Hackman and Oldham's Job Characteristics Model (1980), in which the individual's response to jobs is a function of core job characteristics moderated by individual differences. Although the framework implies that individuals may influence organization-initiated job characteristics, the theory assumes limited individual differences. However, as organizations are pressured to make use of human resources more effectively and efficiently, they see that recognition of individual differences is critical. One particular means to address this matter is job crafting, which expands early job design views to include employees' proactive changes to their jobs (Wrzesniewski \& Dutton, 2001). Job crafting, is "the physical and cognitive changes individuals make in the task or relational boundaries of their work (Wrzesniewski \& Dutton, 2001, p. 179)." Instead of placing employees in the relatively passive position of job design, this approach allows for substantial freedom and independence for individuals. By altering task, cognitive, and relational boundaries in a work setting, employees derive different meanings of their work regardless of the complexity or tier of the job (Berg, Wrzesniewski, \& Dutton., 2010).

When individuals engage in job crafting, it influences individual job attitudes and performance levels such as job satisfaction, job commitment, individual performance, absenteeism (Ghitulescu, 2006), quality of self-image, perceived control, and readiness to change (Lyons, 2008), and it even promotes positive emotions (Ko, 2012). Moreover, as a foundation for the job demands-resources (JD-R) theory, job crafting itself is affected by the level of job demands from the environment and the given job resources of the workplace; the JD-R theory has been explored extensively both theoretically (Bakker \& Demerouti, 2007) and empirically (Akkermans, Schaufeli, Brenninkmeijer, 
\& Blonk, 2013; Bakker, Hakanen, Demerouti, \& Xanthropoulou, 2007; Demerouti, Bakker, \& Fried, 2012; Demerouti, Bakker, Nachreiner, \& Schaufeli, 2001; Hanaken, Schaufeli, \& Ahola, 2008; Tims, Bakker, \& Derks, 2013a; Xanthopoulou, Bakker, Demerouti, \& Schaufeli, 2007a) due to its utility in predicting and understanding employee wellbeing (e.g., burnout, health, motivation, work engagement) and job performance (Bakker \& Demerouti, 2014).

Following Tims and Bakker (2010), we examined job crafting as a key go-between mechanism. To our knowledge, this mediator variable in the JD-R model has been relatively unexplored in empirical terms despite its potential importance and impact to the literature. Adding to this significance, we employed several technological factors in the workplace, assuming the prevalence of a smart work environment in organizations despite different levels of information technology (IT) resources and demands across organizations. Thereby, there are two main implications of our model. First, based on Bakker and Demerouti's JD-R model (2014), we describe the process in which individuals perceive the level of pressure and resources of one's job as well as the alignment or misalignment of one's ideal perception of their job to their actual job environment. The specific job resources - job autonomy, performance feedback, and technology resources - in turn affect specific job crafting methods (i.e., task, cognitive, or relational). Also, we posit that different job demand levels, including work overload, emotional demands, and technology demands, affect individuals' perception of alignment and job crafting through a path independent of job resources.

The second main implication deals with the link between the specific job crafting dimensions and the outcome variables, i.e., work engagement and job stress, in which engagement acts as the motivational stimulator to solve the contingent problem. As a result of perceiving misfit in their work environment, the motivation to restore it to a "fit" level arises, leading employees to take appropriate measures. Job crafting can be a tool to accomplish this misalignment, because employees proactively reduce the known imbalance and engage in related tasks, cognitive abilities, and relational activities to cultivate different meanings and identities (Wrzesniewski, LoBuglio, Dutton, \& Berg, 2013) when dissatisfied with the situation (Frese \& Fay, 2001). Also, because individuals are most likely aware of the causes of the misalignment and how to adjust them according to one's respective situation, job crafting may be the optimal method from an individual's perspective. Thus, our study's main contributions to the JD-R literature is the exploration of the antecedents of job crafting, which, according to the JD-R model, is the effect of job resources and job demands of the working environment and the influence of job crafting as a stimulator for individual work engagement and job stress. In all, our research model examines the important partial mediating variable of job crafting. This links the antecedents (i.e., job demands and job resources) and individual-level outcomes (i.e., work engagement and job stress levels).

More specifically, as a result of the mediating mechanism, individuals exhibit different individual attitudes and behaviors (i.e., work engagement and job stress). These two variables have been demonstrated to be substantial outcomes of fairly independent processes - motivational processes (motivation-driven) and health impairment processes (energy-driven process) - in which job resources are generally the predictors of work motivation, turnover intentions, and work engagement (Bakker, Demerouti, \& Schaufeli, 2003; Bakker et al., 2007; Bakker, Van Veldhoven, \& Xanthopoulou, 2010). Indeed, job resources seemingly become salient and valuable to the tasks at hand (Hakanen, Bakker, \& Demerous, 2005; Bakker et al., 2010), affecting factors such as work engagement, task enjoyment, and commitment. On the other hand, job demands affect exhaustion, job stress, job absenteeism, and repetitive strain injury (RSI) (Bakker et al., 2003; Hakanen, Bakker, \& Schaufeli, 2006). Herein, we focus on the relatively independent processes of job demands and job resources, in which the two factors exhibit relatively separate effects that affect job crafting, ultimately leading to work engagement and job stress.

\section{LITERATURE REVIEW}

\subsection{Job Demands-Resources (JD-R) Theory}

Theoretically, the JD-R theory is based on job design and job stress theories. However, because both lines of research have ignored the role of job demands and/or job resources, causing criticisms such as one-sidedness and simplicity of job descriptions, assumption of an over-static job character, and neglect of the changing nature of jobs (Bakker \& Demerouti, 2014), the JD-R model emerged as a response to complement the shortcomings of the job design and job stress theories. Job demands are defined as "those physical, psychological, social, or organizational aspects of the job 
that require sustained physical and/or psychological (cognitive and emotional) effort or skills and are therefore associated with certain physiological and/or psychological costs" (Bakker \& Demerouti, 2007, p. 312). This implies that there are aspects of the job that entail certain costs and require consistent effort (Demerouti et al., 2012). Job resources are defined as aspects of the job that have a motivational potential to induce work engagement and high performance levels via an instrumental approach by achieving work goals (i.e., extrinsic motivational role) and/or by stimulating personal growth, learning, and development (i.e., intrinsic motivational role).

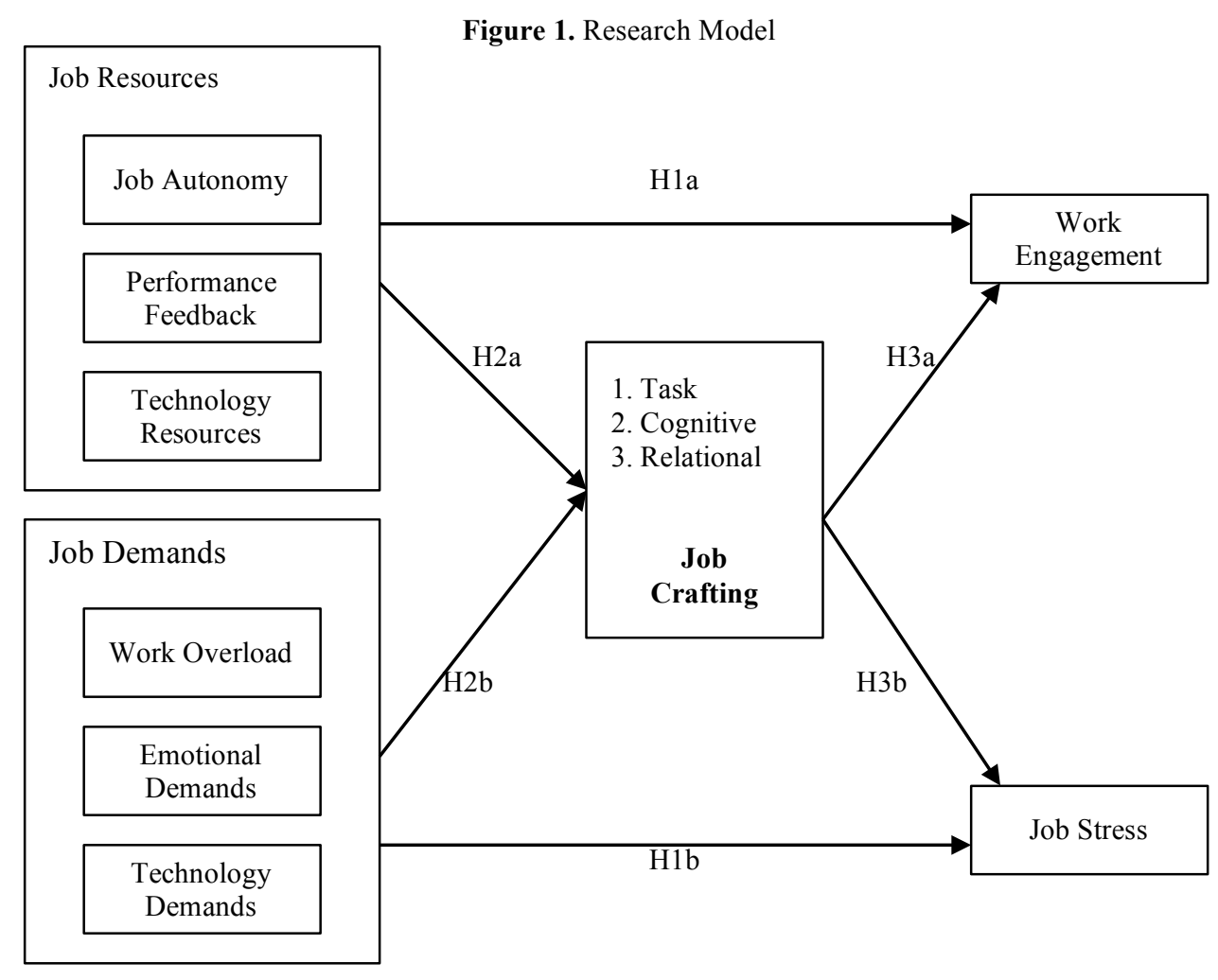

This study tries to identify motivation and impairment factors of the work environment. Figure 1 represents a full model of our research. As mentioned previously, job demands and job resources, the two main job aspects, trigger fairly independent processes. Job demands produce an energetic process that stimulates burnout and exhaustion by depleting energy (Bakker \& Demerouti, 2007; Bakker, Demerouti, \& Euwema, 2005) or a health impairment process that exhaust employees' resources and cause health problems (Bakker \& Demerouti, 2014). Job demands require individual effort and consume energy resources (Bakker \& Demerouti, 2014), arousing an employee's nervous system and activating defense mechanisms. While, at first, employees will strive to handle such demands by exerting energetic resources, continuous exposure wears out individuals' energy reserves, resulting in exhaustion and perhaps burnout (Van den Broeck, Van Ruysseveldt, Vanbelle, \& De Witte, 2013). On the other hand, job resources impose a psychological motivational process that motivates employees to engage in tasks and roles, leading to work enjoyment, work engagement (Bakker et al., 2007), and commitment (Hackman \& Oldham, 1980). This mechanism can be explained by a motivational process in which added resources to one's current total resources facilitate goal attainment, satisfy basic psychological needs for autonomy and competence, and enhance self-efficacy. When such states are fulfilled, one would be motivated to engage in their work and workplace. Therefore, we hypothesized that:

Hypothesis 1a: Job resources (i.e., job autonomy, performance feedback, or technology resources) are positively related to individual work engagement. 
Hypothesis 1b: Job demands (i.e., work overload, emotional demands, or technology demands) are positively related to individual job stress.

\subsection{Job Demands-Resources and Job Crafting}

Based on the JD-R model and building upon Tims and Bakker's (2010) proposed model, we posit that job demands and job resources each induce misalignment when a misbalance is perceived between the characteristics of a job and individual expectations (i.e., needs) or abilities. In other words, when one experiences misbalance regarding one's personal perception of the job and the actual job demands and resources, individuals are likely to engage in activities that reduce or alleviate the perceived situation via individual job crafting activities. Specifically, job crafting activities are divided into three dimensions: (1) task crafting refers to changing the number, scope, and type of job tasks; (2) cognitive crafting regards changing the quality and/or amount of interaction with others encountered in a job; and (3) relational crafting changes social relationships in a work place. Unless there is an agreement between job resources and a person's needs, preferences, job demands and an individual's abilities, individuals consistently strive to level this issue by stabilizing demands and resources in one's work environment via diverse job crafting activities as listed above.

As for the specific job demand dimensions, we employed two commonly cited dimensions, work overload and emotional demands (Bakker et al., 2003; Bakker et al., 2005; Demerouti et al., 2001; Schaufeli \& Bakker, 2004), as well as technology demands, a new dimension in which employees are obliged or pressured to use technology in the work setting. The dimensions of job resources include two frequently studied characteristics: 1) job autonomy and performance feedback (Bakker et al., 2005; Demerouti et al., 2001; Nahrgang, Morgeson, \& Hofmann, 2011; Schaufeli \& Bakker, 2004), which enrich an individual by motivating employees to engage in work tasks or roles, and 2) technology resources, in which employees manage and have access to technological resources in the workplace.

Hypothesis 2a: Job resources (i.e., job autonomy, performance feedback, or technology resources) are positively related to job crafting dimensions (i.e., task, cognitive, and relational crafting).

Hypothesis 2b: Job demands (i.e., work overload, emotional demands, and technology demands) are positively related to job crafting dimensions (i.e., task, cognitive, and relational crafting).

\subsection{Job Crafting and Individual Attitudes and Behaviors}

We examined an extensively researched outcome variable, work engagement, and a relatively under researched but related variable, job stress. Work engagement is an affective-motivational and work-related variable that implies a state of fulfillment, characterized by vigor, dedication, and absorption (Schaufeli, Salanova, Gonzalez-Roma, \& Bakker, 2002). This approach emphasizes the positive balance of engagement, energy, and enthusiasm (Macey \& Schneider, 2008), all characterized by an activated state of positive work-related affect and motivation (Warr \& Inceoglu, 2012). The specific dimensions of work engagement are as follows. Vigor is characterized by high levels of energy, mental endurance, and work perseverance; dedication refers to high involvement in work; and absorption indicates full concentration and engrossment in work (Schaufeli et al., 2002).

Previous research has shown that work engagement is triggered by the main effect of job resources through a motivational process (Hakanen et al., 2006; Schaufeli \& Bakker, 2004), while the interaction effect of job demands and job resources also plays a part in the stimulation of work engagement (Bakker, et al., 2005, 2010; Xanthopoulou, Bakker, Dollard, Demerouti, Schaufeli, Taris, \& Schreurs, 2007b). In regard to the relationship between job crafting and work engagement, past research has shown a significant relationship between the two variables. In a longitudinal study based on Tims and Bakker's (2010) proposition, Tims, Bakker, Derks, and Van Rhenen, (2013b) found that employees impact work engagement, job satisfaction, and burnout by crafting structural (i.e., equivalent to task crafting) or social job resources (i.e., equivalent to relational crafting) via increases in the respected variables. In addition, the amount of challenging job demands partially mediated the relationship between crafting challenging job demands and work engagement and burnout. In a different study, Tims et al. (2013b) examined 525 individuals in a large occupational health services company and investigated job crafting at the individual and team levels. They observed that job crafting influenced both individual work engagement and team work engagement. Team work 
engagement also affected individual work engagement, with each construct leading to positive team performance and individual-level performance.

In the case of the relationship between job crafting and job stress, we employed the energetic process and health impairment process. These processes are centered on the stress adaptation model (Selye, 1956), in which job demands and pressures arouse an individuals' nervous system and activate defense mechanisms. Van den Broeck et al. (2013) elaborated that continued pressures will stimulate employees to use additional energy, which ultimately leads to exhaustion, burnout, health complaints, and RSI (Bakker et al., 2003; Crawford, LePine \& Rich, 2010; Hakanen et al., 2006). In a similar vein, Topcic, Baum, and Kabst (2016), through an empirical analysis of 197 employees, demonstrated that there is a positive association between perceived stress and performance evaluation systems or continuing education/training (i.e., high-performance work practices) - both challenging job demands. Although we did not find any studies that relate job crafting and job stress directly, we posit that because related concepts such as burnout (Nahrgang et al., 2011; Schaufeli \& Bakker, 2004; Tims et al., 2013a), exhaustion, and cynicism (Alarcon, Edwards, \& Menke, 2011; Crawford et al., 2010; Hakanen et al., 2008) have been examined through the JD-R model in empirical and meta-analysis studies, job crafting - a go-between mechanism - is also related to job stress. In particular, Tims et al. (2013b) discovered that crafting structural or social job resources impacts work engagement, job satisfaction, and burnout via the increase of resources (i.e., a fully mediated model).

Thus, we hypothesized:

Hypothesis 3a: Job crafting dimensions (i.e., task, cognitive, and relational crafting) are positively related to individual work engagement.

Hypothesis 3b: Job crafting dimensions (i.e., task, cognitive, and relational crafting) are negatively related to individual job stress.

Lastly, based on the theory and relationships between the variables in our research model, we speculated a partially mediated model. This is so because direct effects of job demands and job resources have been demonstrated empirically based on the JD-R theory, a widely accepted model in the positive organizational scholarship (POS) (Van den Broeck et al., 2013; Wrzesniewski, LoBuglio, Dutton \& Berg, 2013). Also, our logic was based in large on the Input-Process-Output model, in which job demands and resources are the inputs leading to the perception of misalignment and performance of job crafting behavior for alignment. With regard to outcomes, individuals form job attitudes such as job stress and behavioral outcomes such as work engagement. In doing so, we hypothesized that:

Hypothesis 4: Job crafting dimensions (i.e., task, cognitive, and relational crafting) will partially mediate the relationship between job demands/job resources and individual work engagement/job stress.

\section{METHODOLOGY}

\subsection{Procedures and Participants}

Data collection for this study was conducted using survey questionnaires targeting part-time MBA students at a large private university business school and several private organizations in Seoul, Republic of Korea. All participants were informed of the aims of the study and practical details, were assured confidentiality, and were informed that participation in the study was voluntary. A total of 198 surveys were collected as preliminary data; however, after removing 26 incomplete samples, the final sample comprised 172 participants. Our target population consisted of white collar workers in private firms in Korea, adding up to 3000 employees. According to the appropriate sample size suggested by Yount (2006), the sample size of this study is about $6 \%$ of the target population $(172 / 3,000)$, which is higher than Yount (2006)'s proposed rate of 5\% (Abioye, 2016).

The average age of the respondents was 33.6 years $(\mathrm{SD}=7.8)$, and $52.9 \%$ of the sample were female. With regard to job levels, rank-and-file members or associates (i.e., non-managerial) consisted of $50.0 \%$ of the participants, while the remaining were managers and senior managers (i.e., managers). In addition, the sample consisted of industry sectors of manufacturing $(14.5 \%)$, finance $(8.1 \%)$, retail $(5.8 \%)$, service $(30.2 \%)$, and others $(41.3 \%)$. Finally, analysis of the 
education levels of participants showed that $97.1 \%$ had at least an undergraduate diploma from a university. We measured all the variables of our research model at one time; thus, the study had a cross-sectional between-cases design.

\subsection{Measures}

We adopted frequently used and well-validated measures in the literature for our questionnaire. All items for our variables were measured on a 5-point Likert Scale, ranging from 1 (never) to 5 (always). The data from the responses were coded to indicate that high scores defined high job demands, job resources, job crafting, work engagement, and job stress. All items were translated to Korean, while two researchers who had no association with our study crossexamined our dimensions (Table 1).

Table 1. Measurement Items

\begin{tabular}{|c|c|c|}
\hline \multicolumn{2}{|c|}{ Constructs } & Items \\
\hline \multirow{3}{*}{ Job Resource } & Job Autonomy & $\begin{array}{l}\text { 1. I have freedom in carrying out my work activities. } \\
\text { 2. I have influence in the planning of my work activities. } \\
\text { 3. I have an influence on the pace of work. } \\
\text { 4. I decide how my work is executed on my own. } \\
\text { 5. I decide on the content of my work activities by myself. }\end{array}$ \\
\hline & $\begin{array}{l}\text { Performance } \\
\text { Feedback }\end{array}$ & $\begin{array}{l}\text { 1. I receive sufficient information on the purpose of my work. } \\
\text { 2. I receive sufficient information on the results of my work. } \\
\text { 3. My work gives me the opportunity to check on how well I am doing my work. } \\
\text { 4. My work provides me with direct feedback on how well I am doing my work. } \\
\text { 5. My superior informs me about how well I am doing my work. } \\
\text { 6. My colleagues inform me about how well I am doing my work. }\end{array}$ \\
\hline & $\begin{array}{l}\text { Technology } \\
\text { Resources }\end{array}$ & $\begin{array}{l}\text { 1. A lot of time is required to learn information technology. } \\
\text { 2. I have access to information technology anytime. } \\
\text { 3. I have various IT appliances (PC, Smart phones, Tables PCs) to utilize information } \\
\text { technology }\end{array}$ \\
\hline \multirow{3}{*}{ Job Demand } & Wok Overload & $\begin{array}{l}\text { 1. I must work very fast. } \\
\text { 2. I have too much work to do. } \\
\text { 3. I must work extra hard to complete something. } \\
\text { 4. I work under time pressure. } \\
\text { 5. I must be hurry. }\end{array}$ \\
\hline & $\begin{array}{l}\text { Emotional } \\
\text { Demands }\end{array}$ & $\begin{array}{l}\text { 1. My work demand a lot from me emotionally. } \\
\text { 2. I am confronted with things that affect me personally in my work. } \\
\text { 3. My work put me in emotionally upsetting situations. }\end{array}$ \\
\hline & $\begin{array}{l}\text { Technology } \\
\text { Demands }\end{array}$ & $\begin{array}{l}\text { 1. My supervisor expects me to utilize information technology to perform tasks. } \\
\text { 2. My colleagues expect me to utilize information technology to perform tasks. } \\
\text { 3. My work demands me to perform tasks by using information technology. }\end{array}$ \\
\hline \multirow{3}{*}{ Job Crafting } & Task Crafting & $\begin{array}{l}\text { 1. I introduce new approaches to improve my work. } \\
\text { 2. I change the scope or types of tasks that I complete at work. } \\
\text { 3. I introduce new work tasks that I think better suit my skills or interests. } \\
\text { 4. I choose to take on additional tasks at work. } \\
\text { 5. I give preference to work tasks that suit my skills or interests. }\end{array}$ \\
\hline & Cognitive Crafting & $\begin{array}{l}\text { 1. I think about how my job gives my life purpose. } \\
\text { 2. I remind myself about the significance my work has for the success of the organization. } \\
\text { 3. I remind myself of the importance of my work for the broader community. } \\
\text { 4. I think about the ways in which my work positively impacts my life. } \\
\text { 5. I reflect on the role my job has for my overall well-being. }\end{array}$ \\
\hline & Relational Crafting & $\begin{array}{l}\text { 1. I make an effort to get to know people well at work. } \\
\text { 2. I organize or attend work related social functions. } \\
\text { 3. I organize special events in the workplace (e.g., celebrating a co-worker's birthday). } \\
\text { 4. I choose to mentor new employees (officially or unofficially). } \\
\text { 5. I make friends with people at work who have similar skills or interests. }\end{array}$ \\
\hline
\end{tabular}

(Table 1 continued on next page) 
(Table 1 continued)

\begin{tabular}{|c|c|c|}
\hline \multicolumn{2}{|c|}{ Constructs } & Items \\
\hline \multirow{3}{*}{$\begin{array}{l}\text { Work } \\
\text { Engagement }\end{array}$} & Vigor & $\begin{array}{l}\text { 1. At my work, I feel bursting with energy. } \\
\text { 2. At my job, I feel strong and vigorous. } \\
\text { 3. When I get up in the morning, I feel like going to work. }\end{array}$ \\
\hline & Dedication & $\begin{array}{l}\text { 1. I am enthusiastic about my job. } \\
\text { 2. My job inspires me. } \\
\text { 3. I am proud of the work that I do. }\end{array}$ \\
\hline & Absorption & $\begin{array}{l}\text { 1. I feel happy when I am working intensely. } \\
\text { 2. I am immersed in my work. } \\
\text { 3. I get carried away when I am working. }\end{array}$ \\
\hline Job Stress & & $\begin{array}{l}\text { 1. I know clear goals/objectives for my job. } \\
\text { 2. I know exactly what is expected of me. } \\
\text { 3. I know how my performance is going to be evaluated. }\end{array}$ \\
\hline
\end{tabular}

\subsubsection{Job Demands}

To examine job demands, we examined work overload, emotional demands (both frequently studied dimensions), and technology demands. Work overload $(\alpha=.86)$ and emotional demands $(\alpha=.66)$ were measured by selecting related items from the Questionnaire on the Experience and Evaluation of Work (QEEW) developed by Van Veldhoven and Meijman (2005). This questionnaire has been used extensively in JD-R studies, although the dimensions used vary from study to study. The original items were shortened to fit the work context of a smart work environment in Korean firms, leading to five items for the former and three items for the latter. For technology demands $(\alpha=.92)$, we did not find an existing construct related to our study's purpose, so we developed a three-item construct based on the technology acceptance model (TAM) that centers around social normative pressure (Lou, Luo, and Strong, 2000) and social influences (Venkatesh and Davis, 2000) to utilize technological features.

\subsubsection{Job Resources}

There are three dimensions for job resources: job autonomy $(\alpha=.85)$, performance feedback $(\alpha=.88)$, and technology resources $(\alpha=.67)$. All items were derived from Van Veldhoven and Meijman's (2005) Questionnaire on the Experience and Evaluation of Work (QEEW). A shortened version of each dimension was used to fit our study's purpose and environment. Similar to technology demands, we developed a three-item construct for technology resources. The items used assessed the accessibility and ease of use of technology.

\subsubsection{Job Crafting}

Although the JD-R literature dominantly operationalizes job crafting with the scale developed by Tims and Baker (2010), we decided to use Slemp and Vella-Brodrick's (2013) new scale, the Job Crafting Questionnaire (JCQ). This construct is more related to Wrzesniewski and Dutton's (2001) classification of job crafting by measuring task job crafting $(\alpha=.57)$, relational job crafting $(\alpha=.84)$, and cognitive job crafting $(\alpha=.73)$. We used JCQ-K for our survey questionnaire, a scale adjusted to the firm environment in Korea (Lim, Ha, Oh, \& Sohn, 2014).

\subsubsection{Work Engagement}

Work engagement ( $\alpha=.91$ ) was measured using Schaufeli, Bakker, and Salanova's (2006) nine-item Utrecht Work Engagement Scale (UWES). There were three items each for vigor, dedication, and absorption.

\subsubsection{Job Stress}

We included items indicating role stress $(\alpha=.74)$ to operationalize job stress. Three role stress items were derived from Babakus, Yavas, and Ashill's (2009) research, which was directly related to one's job in terms of role ambiguity and role conflict and thus was modified to our study's purpose. 


\subsubsection{Control Variables}

We included age, job level, education level, organizational tenure, and social desirability. We assumed that, according to an individual's age, job level, education level, and organizational tenure, people would have different capacity levels to attain job resources and to cope with job demands. Because respondents reported on independent variables and dependent variables simultaneously, we also included social desirability, a psychological state of respondents and a direct cause of common method bias (Park, Kim, Jeong, and Huh, 2007). Social desirability was measured with seven items $(\alpha=.79)$ from Stöber's (2001) The Social Desirability Scale-17 (SDS-17). Examples for this scale include, "I always admit my mistakes openly and face the potential negative consequences," and "I always accept others" opinions, even when they don't agree with my own."

\subsection{Statistical Analysis}

To test our hypotheses, we employed the SPSS 21.0 software package to perform hierarchical regression analyses. As a preliminary step for our analyses, Principal Components Analysis was performed to define the various constructs and dimensions of our research model's variables. For the main analysis, hierarchical regression analysis was performed multiple times to test the effects and relationships of our antecedents, mediators, and outcome variables. To test the mediation effects of our model, we employed Baron and Kenny's (1986) method, following a four-step process. First, we studied the relationships between the individual variables (i.e., job resources and job demands) and the mediation variable (i.e., job crafting), then we assessed the significance of the relationships between the individual variables and dependent variables (i.e., work engagement and job stress). For the third step, the significant relations between the individual variables and mediation variable and dependent variables were tested, leading to the final step in which the standard coefficients between the second and third steps were compared. When the mediator was added in the third step, if the relationship between the independent variable and dependent variable was not significant, the model was considered to be fully mediated. If the relationship was statistically significant but had a lower coefficient level, it was assumed to be partially mediated.

\section{EMPIRICAL RESULTS}

Table 2 presents the descriptive statistics and inter-correlations of the control, independent, and dependent variables of our research. Task job crafting was positively related to job autonomy $(r=.44, p<.01)$, performance feedback $(r$ $=.34, \mathrm{p}<.01)$, technology resources $(\mathrm{r}=.16, \mathrm{p}<.05)$, and work engagement $(\mathrm{r}=.54, \mathrm{p}<.01)$. Cognitive job crafting was positively related to emotional demands $(\mathrm{r}=.18, \mathrm{p}<.05)$, job autonomy $(\mathrm{r}=.22, \mathrm{p}<.01)$, performance feedback $(\mathrm{r}=.22, \mathrm{p}<.01)$, work engagement $(\mathrm{r}=.38, \mathrm{p}<.01)$, and job stress $(\mathrm{r}=.23, \mathrm{p}<.01)$. Also, relational job crafting was related to emotional demands $(\mathrm{r}=.17, \mathrm{p}<.05)$, technology demands $(\mathrm{r}=.20, \mathrm{p}<.05)$, job autonomy $(\mathrm{r}=.35, \mathrm{p}<.01)$, performance feedback $(\mathrm{r}=.35, \mathrm{p}<.01)$, technology resources $(\mathrm{r}=.52, \mathrm{p}<.01)$, and job stress $(\mathrm{r}=.42, \mathrm{p}<.01)$.

Table 2. Descriptive Statistics and Intercorrelations

\begin{tabular}{|c|c|c|c|c|c|c|c|c|c|c|c|c|c|}
\hline Variable & Mean & S D & 1 & 2 & 3 & 4 & 5 & 6 & 7 & 8 & 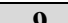 & 10 & 11 \\
\hline 1. JC-Task & 3.70 & .66 & 一 & $.34^{* *}$ & $.40^{* *}$ & $.26^{* *}$ & .07 & $.15^{*}$ & $.44^{* *}$ & $.34^{* *}$ & $.16^{*}$ & $.54^{* *}$ & $.36^{* *}$ \\
\hline 2. JC - Cognitive & 3.91 & .74 & & 一 & $.30^{* *}$ & .04 & $.18^{*}$ & -.01 & $.22^{* *}$ & $.22^{* *}$ & .06 & $.38^{* *}$ & $.23^{* *}$ \\
\hline 3. JC-Relational & 3.70 & .68 & & & 一 & .02 & $.17^{*}$ & $.20^{*}$ & $.35^{* *}$ & $.35^{* *}$ & $.23^{* *}$ & $.52^{* *}$ & $.42^{* *}$ \\
\hline 4. JD - Overload & 3.48 & .83 & & & & 一 & $.27^{* *}$ & $.16^{*}$ & .02 & .00 & -.03 & .00 & .02 \\
\hline 5. JD - Emotional & 3.20 & .90 & & & & & 一 & .03 & -.06 & .01 & -.05 & .02 & .02 \\
\hline 6. JD - Technology & 3.36 & 1.01 & & & & & & 一 & .10 & $.18^{*}$ & $.41^{* *}$ & .14 & $.21^{* *}$ \\
\hline 7. JR - Autonomy & 3.68 & .78 & & & & & & & 一 & $.44^{* *}$ & $.27^{* *}$ & $.54^{* *}$ & $.41^{* *}$ \\
\hline 8. JR - Feedback & 3.51 & .79 & & & & & & & & 一 & .14 & $.55^{* *}$ & $.64^{* *}$ \\
\hline 9. JR - Technology & 3.66 & .84 & & & & & & & & & 一 & $.23^{* *}$ & $.23^{* *}$ \\
\hline 10. Work engagement & 3.43 & .77 & & & & & & & & & & 一 & $.61^{* *}$ \\
\hline 11. Job stress & 3.90 & .70 & & & & & & & & & & & 一 \\
\hline
\end{tabular}

JC: Job Crafting; JD: Job Demands, JR: Job Resources 
We tested our hypotheses through multiple regression models. Table 3 indicates the results of the relationships between job demands/job resources and work engagement/job stress (i.e., H1a \& H1b). Results show that work engagement was positively associated with job autonomy $(\beta=.34, \mathrm{p}<.01)$ and performance feedback $(\beta=.30, \mathrm{p}<$ $.01)$, while job stress was positively associated with technology resources $(\beta=.02, p<.01)$ and with technology demands $(\beta=.08, \mathrm{p}<.10)$. We found that both technological resources and demands induced job stress.

Our second hypotheses posited that job resources and job demands are associated with the job crafting dimensions (i.e., H2a \& H2b). The results are presented in Table 4 and show that work overload $(\beta=.24, \mathrm{p}<.01)$ and job autonomy $(\beta=.34, \mathrm{p}<.01)$ significantly predicted task job crafting, while emotional demands $(\beta=.20, \mathrm{p}<.01)$ and job autonomy $(\beta=.19, \mathrm{p}<.05)$ were each related to cognitive job crafting. Regarding to relational job crafting, emotional demands $(\beta=.18, \mathrm{p}<.01)$ and job autonomy $(\beta=.21, \mathrm{p}<.01)$ were positively related, while technology demands were associated at a marginally significant level $(\beta=.13, \mathrm{p}<.10)$. The results imply that individuals with job autonomy more actively engage in all three job crafting activities by making use of their freedom during work, and individuals who feel emotional pressure at work strive to resolve stress through cognitive crafting and relational crafting activities.

To test the third hypotheses (i.e., H3a \& H3b), we regressed individual work engagement and job stress on the specific job crafting dimensions. The results (Table 5$)$ show that task job crafting $(\beta=.31, \mathrm{p}<.01)$, cognitive job crafting $(\beta=$ $.15, \mathrm{p}<.05)$, and relational job crafting $(\beta=.29, \mathrm{p}<.01)$ were all positively associated with work engagement, and only relational job crafting was significantly related with job stress $(\beta=.22, \mathrm{p}<.01)$. Also, all job crafting activities exhibited a positive effect on work engagement. Meanwhile, only relational job crafting activities were found to have both positive and negative effects simultaneously (i.e., both work engagement and job stress).

Lastly, to examine whether our mediation hypothesis held, we simultaneously regressed work engagement and job stress (i.e., outcome variables) on job demands and job resources (i.e., antecedents) as well as mediators (three job crafting activities). Table 6 showed that the relationship between job autonomy $(\beta=.20, p<.01)$ and work engagement was partially mediated by task job crafting $(\beta=.23, \mathrm{p}<.01) /$ cognitive job crafting $(\beta=.13, \mathrm{p}<.05) /$ relational job crafting $(\beta=.21, \mathrm{p}<.01)$. This was confirmed by comparing the standardized coefficient scores of job autonomy in Table $3(\beta=.34)$ and Table $6(\beta=.20)$. In addition, the association between feedback $(\beta=.26, \mathrm{p}<.01)$ and work engagement was also partially mediated by task job crafting $(\beta=.23, \mathrm{p}<.01) / \operatorname{cognitive}$ job crafting $(\beta=.13, \mathrm{p}<$ $.05) /$ relational job crafting $(\beta=.21, \mathrm{p}<.01)$, such that the regression score decreased (Table $3, \beta=.30$ vs Table $6, \beta=$ .26) when mediators (i.e., job crafting dimensions) were added to the model. In terms of job stress, no job crafting activities enacted mediating effects. Table 7 summarized the research findings.

Table 3. Impacts of Job Demands and Job Resources on Work Engagement and Job Stress

\begin{tabular}{|c|c|c|c|c|c|}
\hline & & \multicolumn{2}{|c|}{ Work engagement } & \multicolumn{2}{|c|}{ Job stress } \\
\hline \multirow{5}{*}{ Step 1} & Age & .21 & .12 & $.16 \dagger$ & .09 \\
\hline & Education & .04 & -.03 & $.19^{* *}$ & .15 \\
\hline & Org tenure & -.02 & -.08 & .04 & -.01 \\
\hline & Job level dummy & .02 & -.04 & -.06 & -.04 \\
\hline & Desirability & $.42^{* *}$ & $.22^{* *}$ & $.45^{* *}$ & $.25^{* *}$ \\
\hline \multirow{8}{*}{ Step 2} & Work overload (JD) & & -.03 & & -.00 \\
\hline & Emotional demand (JD) & & .03 & & .01 \\
\hline & Technology demands (JD) & & .05 & & $.08 \dagger$ \\
\hline & Job autonomy $(\mathrm{JR})$ & & $.34^{* *}$ & & .10 \\
\hline & Performance feedback (JR) & & $.30^{* *}$ & & .46 \\
\hline & Technology resources (JR) & & .03 & & $.02^{* *}$ \\
\hline & Total R2 & .21 & .44 & .26 & .48 \\
\hline & $\triangle \mathrm{F}$ & $9.86^{* *}$ & $12.67^{* *}$ & $13.12^{* *}$ & $12.82^{* *}$ \\
\hline
\end{tabular}

Note: $\mathrm{N}=172$

$\dagger \mathrm{p}<.10, * \mathrm{p}<.05, * * \mathrm{p}<.01$

JD: Job Demands; JR: Job Resources 
Table 4. Impacts of Job Demands and Job Resources on Job Crafting

\begin{tabular}{|c|c|c|c|c|c|c|c|}
\hline & & $\begin{array}{c}\text { Task } \\
\text { JC }\end{array}$ & $\begin{array}{c}\text { Task } \\
\text { JC }\end{array}$ & $\begin{array}{c}\text { Cog } \\
\text { JC }\end{array}$ & $\begin{array}{c}\text { Cog } \\
\text { JC }\end{array}$ & $\begin{array}{c}\text { Rel } \\
\text { JC }\end{array}$ & $\begin{array}{l}\text { Rel } \\
\text { JC }\end{array}$ \\
\hline \multirow{5}{*}{$\begin{array}{l}\text { Step 1: } \\
\text { Control }\end{array}$} & Age & .13 & .01 & -.03 & -.11 & $.17 \dagger$ & .09 \\
\hline & Education & .01 & -.02 & .05 & .05 & .02 & -.02 \\
\hline & Org tenure & .04 & -.02 & -.08 & -.08 & .00 & -.03 \\
\hline & Job level dummy & .07 & .05 & .10 & .10 & -.09 & -.07 \\
\hline & Desirability & $.43^{* *}$ & $.35^{* *}$ & $.40^{* *}$ & $.36^{* *}$ & $.38^{* *}$ & $.28^{* *}$ \\
\hline \multirow{8}{*}{ Step 2} & Work overload (JD) & & $.24^{* *}$ & & .01 & & -.05 \\
\hline & Emotional demand (JD) & & .01 & & $.20^{* *}$ & & $.18^{* *}$ \\
\hline & Technology demands (JD) & & .09 & & .02 & & $.13 \dagger$ \\
\hline & Job autonomy $(\mathrm{JR})$ & & $.34^{* *}$ & & $.19^{*}$ & & $.21^{* *}$ \\
\hline & Performance feedback (JR) & & .05 & & .04 & & .11 \\
\hline & Technology resources (JR) & & -.05 & & -.07 & & .04 \\
\hline & Total R2 & .20 & .35 & .15 & .20 & .17 & .26 \\
\hline & $\triangle \mathrm{F}$ & $9.39^{* *}$ & $7.55^{* *}$ & $7.09^{* *}$ & $2.62^{*}$ & $7.86^{* *}$ & $4.53^{* *}$ \\
\hline
\end{tabular}

Note: $\mathrm{N}=172, \dagger \mathrm{p}<.10, * \mathrm{p}<.05, * * \mathrm{p}<.01$

JC: Job Crafting; JD: Job Demands; JR: Job Resources

Table 5. Impacts of Job Crafting on Work Engagement and Job Stress

\begin{tabular}{|c|c|c|c|c|c|}
\hline \multirow{6}{*}{$\begin{array}{l}\text { Step 1: } \\
\text { Control }\end{array}$} & & \multicolumn{2}{|c|}{ Work engagement } & \multicolumn{2}{|c|}{ Job stress } \\
\hline & Age & $.21^{*}$ & $.13 \dagger$ & $.16 \dagger$ & .11 \\
\hline & Education & .04 & .02 & $.19^{* *}$ & $.18^{* *}$ \\
\hline & Org tenure & -.02 & -.02 & .04 & .04 \\
\hline & Job level dummy & .02 & .01 & -.06 & -.05 \\
\hline & Desirability & $.42^{* *}$ & $.12 \dagger$ & $.45^{* *}$ & $.31^{*}$ \\
\hline \multirow{5}{*}{ Step 2} & Task JC & & $.31^{* *}$ & & .11 \\
\hline & Cognitive JC & & $.15^{*}$ & & .01 \\
\hline & Relational JC & & $.29^{* *}$ & & $.22^{* *}$ \\
\hline & Total R2 & .21 & .43 & .26 & .31 \\
\hline & $\triangle \mathrm{F}$ & $9.86^{* *}$ & $22.10^{* *}$ & $13.12^{* *}$ & $4.99^{* *}$ \\
\hline
\end{tabular}

Note: $\mathrm{N}=172, \dagger \mathrm{p}<.10,{ }^{*} \mathrm{p}<.05,{ }^{* *} \mathrm{p}<.01$

JC: Job Crafting

Table 6. Impacts of Job Demands, Job Resources, and Job Crafting on Outputs (Partial Mediation Model)

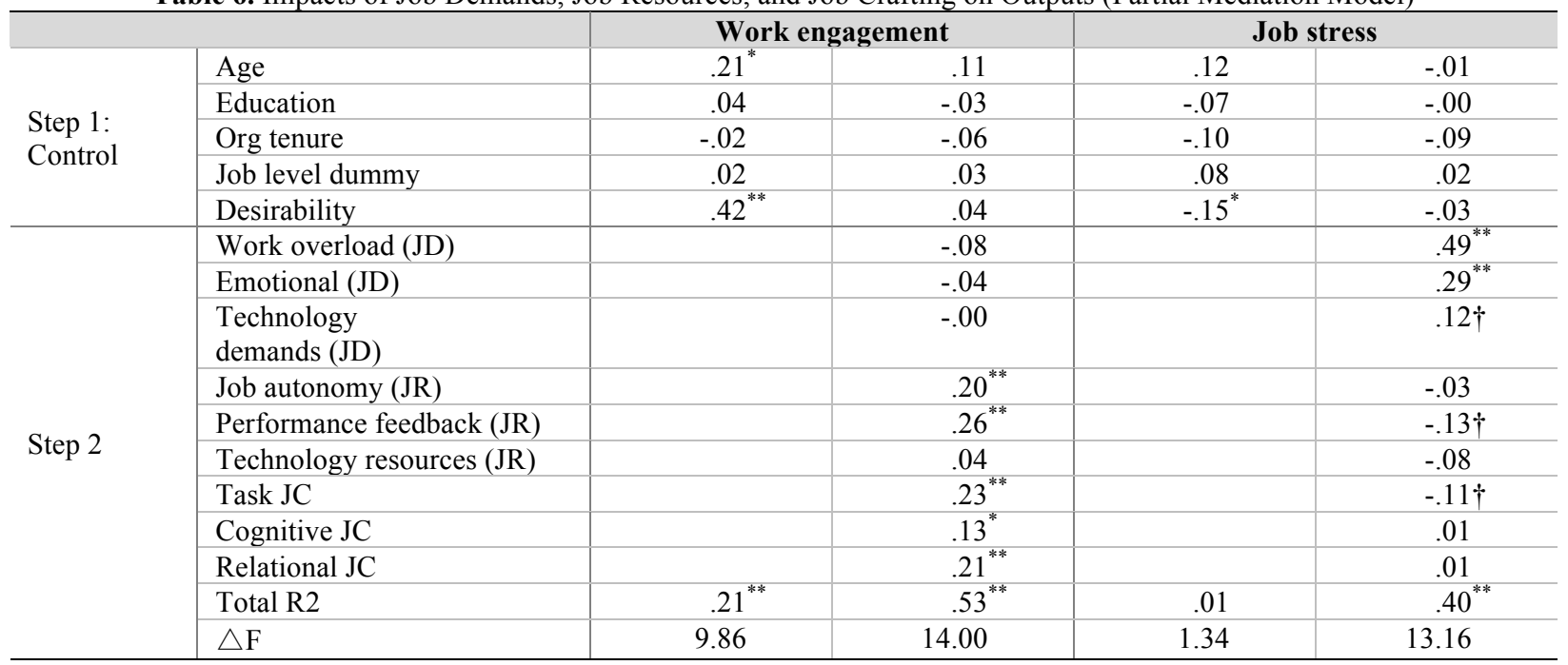

Note: $\mathrm{N}=172$

$\dagger \mathrm{p}<.10, * \mathrm{p}<.05, * * \mathrm{p}<.01$

JD: Job Demands; JR: Job Resources 
Table 7. Summary of Research Findings

\begin{tabular}{|c|c|}
\hline & Supported Hypotheses \\
\hline H1a & Job Autonomy/Performance Feedback -> Work Engagement \\
\hline $\mathrm{H} 1 \mathrm{~b}$ & Technology Demands $->$ Job Stress (Marginally Significant) \\
\hline $\mathrm{H} 2 \mathrm{a}$ & Job Autonomy -> Task Crafting/Cognitive Crafting/Relational Crafting \\
\hline $\mathrm{H} 2 \mathrm{~b}$ & $\begin{array}{l}\text { Work Overload -> Task Crafting } \\
\text { Emotional Demand -> Cognitive Crafting/Relational Crafting }\end{array}$ \\
\hline $\mathrm{H} 3 \mathrm{a}$ & Task Crafting/Cognitive Crafting/Relational Crafting -> Work Engagement \\
\hline $\mathrm{H} 3 \mathrm{~b}$ & Relational Crafting $->$ Job Stress \\
\hline \multirow[t]{2}{*}{ H4 } & Job Autonomy -> Task Crafting/Cognitive Crafting/Relational Crafting -> Work Engagement \\
\hline & Performance Feedback $->$ Task Crafting/Cognitive Crafting/Relational Crafting $->$ Work Engagement \\
\hline
\end{tabular}

\section{CONCLUSIONS}

Our research demonstrated that job crafting acts as a mechanism that links job demands and job resources with individual work outcomes such as work engagement and job stress. In this study, we verified that two of the three defined job resource factors provided a positive effect on work engagement by acting as motivational factors. However, analyses did not prove that job demand factors caused job stress as a de-motivational factor, although technology demands did cause job stress at a marginally significant level. In addition, job crafting, a bottom-up job design strategy, was found to have a statistically significant effect on the positive outcome, work engagement, but not the negative outcome, job stress. Finally, all three job crafting activities were found to partially mediate the effect of job resources on work engagement. On the other hand, although not hypothesized in our study, job crafting (i.e., task crafting) fully mediated the effect of two of job demand factors (i.e., work overload/emotional demand) on work engagement. Our study also found that job demand, which is assumed to cause negative outcomes, causes positive outcomes through job crafting activities. Work overload did not directly affect work engagement, but instead was found to have a statistically significant effect on task crafting activity. Also, emotional demand also had no direct effect on work engagement, but still was found to influence work engagement via cognitive/relational crafting activities. In all, we found partial but somewhat strong support for our initially proposed research model. It shows that, despite a strong direct effect between job demands/job resources and outcome variables, job crafting plays an important role as a strong go-between mechanism, implying a full or partially mediated process between certain antecedents and outcomes. This implies that individual job crafting, a bottom-up process, may be as important as topdown traditional job design tactics or even more important than its predecessor in light of the emphasis of individuals' roles in present day organizations.

Although our data and results show partial yet strong support for our hypotheses, our study is not without limitations. First, our data was based on a cross-sectional design model, compromising determination of causation of our variables. We hope to address this issue in future research by performing analysis based on structural equation modeling (SEM) and comparing the model fit between various models. Also plausible is collection of data by employing a longitudinal research design, with surveys distributed in two separate periods. Second, we measured the antecedents, mediation variable, and outcome variables from one group of respondents, which gives rise to common method bias issues. However, we partially dealt with this problem by measuring social desirability and employing it as a control variable in our analysis, as suggested by Park et al. (2007).

Lastly, although we included misalignment, also conceptualized as the Person-Job misfit, to explain our model in a logical sense, the current study did not include it as an operationalized variable. To be specific on this issue, individuals experience good person-job fit when job characteristics are aligned with the personal needs and abilities of the employees (Kristof-Brown, Zimmerman, \& Johnson, 2005). Specifically, Kristof's (1996) conceptualization of individual complementary fit at work was employed for our logic. Employees perceive fit when the demands of a job and the abilities of a person achieve balance or when the needs of an individual are met by the organization's supplies. The former may be explained through job demands, in which individuals experience misfit when the demands of the job are not compatible with the employees' knowledge, skills, and abilities. The latter explains the process in which an employee's needs and preferences are fulfilled by the presented job resources and the personal resources one possesses (Kristof, 1996). Researchers may measure P-J misfit and P-J fit at separate periods, following a longitudinal research model proposed by Tims and Bakker (2010). 


\section{ACKNOWLEDGEMENT}

This work was supported by the Ministry of Education of the Republic of Korea and the National Research Foundation of Korea (NRF-2015S1A5A2A03048360)

\section{AUTHOR BIOGRAPHIES}

Sang-Hoon Lee is currently a Ph. D. student at the University of Illinois at Urbana-Champaign of the School of Labor and Employment Relations. He received his Master of Science from Hanyang University Business School, concentrating in organizational behavior and human resource management. Currently, his research interests lie in work meaningfulness, job crafting, proactive behaviors, and identity and identity processes.

Yuhyung Shin is a Professor of Organizational Behavior at Hanyang University, Seoul, Korea. She received her Ph. D. from Columbia University. Her research interests include person-organization fit, work regulatory focus, and proactivity and creativity in teams and organizations.

Seung Ik Baek (Corresponding Author) received his MBA and Ph. D. from George Washington University (Washington, DC). He is a professor at the Business School, Hanyang University (Seoul, Korea). Before joining Hanyang University, he was an assistant professor at Saint Joseph's University (Philadelphia, PA) and Georgia State University (Atlanta, GA). His main research interests include service design, human-computer interactions, design thinking, and smart works.

\section{REFERENCES}

Abioye, O. (2016). Privatisation of the Nigerian Railway Corporation: An evaluation of critical choices (Doctoral Dissertation). Retrieved from http://hdl.handle.net/10369/7860

Alarcon, G. M., Edwards, J. M., \& Menke, L. E. (2011). Student burnout and engagement: A test of the conservation of resources theory. Journal of Psychology, 145(3), 211-227. doi: 10.1080/00223980.2011.555432

Akkermans, J., Schaufeli, W. B., Brenninkmeijer, V., \& Blonk, W. B. (2013). The role of career competencies in the Job Demands-Resources model. Journal of Vocational Behavior, 83(3), 356-366. doi: 10.1016/j.jvb.2013.06.011

Babakus, E., Yavas, U., \& Ashill, N. J. (2009). The role of customer orientation as a moderator of the job demand-burnoutperformance relationship: A surface-level trait perspective. Journal of Retailing, 85(4), 480-492. doi: 10.1016/j.jretai.2009.07.001

Bakker, A. B., \& Demerouti, E. (2007). The job demands-resources model: State of the art. Journal of Managerial Psychology, 22(3), 209-328. doi: 10.1108/02683940710733115

Bakker, A. B., \& Demerouti, E. (2014). Job demands-resources theory, In P. Y. Chen and C. L. Cooper (Eds.), Wellbeing: $A$ complete reference guide, volume III, work and wellbeing. United States: John Wiley \& Sons.

Bakker, A. B., Demerouti, E., \& Euwema, M. (2005). Job resources buffer the impact of job demands on burnout. Journal of Occupational Health Psychology, 10(2), 170-180. doi: 10.1037/1076-8998.10.2.170

Bakker, A. B., Demerouti, E., \& Schaufeli, W. B. (2003). Dual processes at work in a call centre: An application of the job demands-resources model. European Journal of Work and Organizational Psychology, 12(4), 393-417. doi: 10.1080/13594320344000165

Bakker, A. B., Hakanen, J. J., Demerouti, E., \& Xanthopoulou, D. (2007). Job resources boost work engagement, particularly when job demands are high. Journal of Educational Psychology, 99(2), 274-284. doi: 10.1037/0022-0663.99.2.274

Bakker, A. B., ten Brummelhuis, L. L., Prins, J. T., \& van der Heijden, F. M. M. A. (2011). Applying the job demands-resources model to the work-home interface: A study among medical residents and their partners. Journal of Vocational Behavior, 79: 170-180. doi: 10.1016/j.jvb.2010.12.004

Bakker, A. B., Van Veldhoven, M., \& Xanthopoulou, D. (2010). Beyond the demand-control model: Thriving on high job demands and resources. Journal of Personnel Psychology, 9(1), 3-16. doi: 10.1027/1866-5888/a000006

Baron, R. M., \& Kenny, D. A. (1986). The moderator-mediator variable distinction in social psychological research: Conceptual, strategic, and statistical considerations. Journal of Personality and Social Psychology, 51(6), 1173-1182. doi: 10.1037/0022-3514.51.6.1173

Berg, J. M., Wrzesniewski, A., \& Dutton, J. E. (2010). Perceiving and responding to challenges in job crafting at different ranks: When proactivity requires adaptivity. Journal of Organizational Behavior, 31, 158-186. doi: 10.1002/job.645

Crawford, E. R., LePine, J. A., \& Rich, B. L. (2010). Linking job demands and resources to employee engagement and burnout: A theoretical extension and meta-analytic test. Journal of Applied Psychology, 95(5), 834-848. doi: 10.1037/a0019364 
Demerouti, E., Bakker, A. B., \& Fried, Y. (2012). Work orientations in the job demands-resources model. Journal of Managerial Psychology, 27(6), 557-575. doi: 10.1108/02683941211252428

Demerouti, E., Bakker, A. B., Nachreiner, F., \& Schaufeli, W. B. (2001). The job demands-resources model of burnout. Journal of Applied Psychology, 86(3), 499-512. doi: 10.1037/0021-9010.86.3.499

Frese, M., \& Fay, D. (2001). Personal initiative (PI): An active performance concept for work in the 21st century. In B. M. Staw \& R. M. Sutton (Eds.), Research in Organizational Behavior, 23, 133-187. doi: 10.1016/S0191-3085(01)23005-6

Ghitulescu, B. E. (2006). Shaping tasks and relationships at work: Examining the antecedents and consequences of employee job crafting (Doctoral dissertation). Retrieved from http://d-scholarship.pitt.edu/id/eprint/10312

Hackman, J. R., \& Oldham, G. R. (1980). Work redesign. Reading, MA: Addison-Wesley.

Hakanen, J. J., Bakker, A. B., \& Demerouti, E. (2005). How dentists cope with their job demands and stay engaged: The moderating role of job resources. European Journal of Oral Sciences, 113(6), 479-487. doi: 10.1111/j.16000722.2005.00250.x

Hakanen, J. J., Bakker, A. B., \& Schaufeli, W. B. (2006). Burnout and work engagement among teachers. Journal of School Psychology, 43(6), 495-513. doi: 10.1016/j.jsp.2005.11.001

Hakanen, J. J., Schaufeli, W. B., \& Ahola, K. (2008). The job demands-resources model: A three-year cross-lagged study of burnout, depression, commitment, and work engagement. Work \& Stress, 22(3), 224-241. doi: 10.1080/02678370802379432

Ko, I. (2012). Crafting of a job: Creating optimal experiences at work (Doctoral dissertation). Retrieved from http://gradworks.umi.com/34/66/3466478.html

Kristof, A. L. (1996). Person-organization fit: An integrative review of its conceptualizations, measurement, and implications. Personnel Psychology, 49(1), 1-49. doi: 10.1111/j.1744-6570.1996.tb01790.x

Kristof-Brown, A. L., Zimmerman, R. D., \& Johnson, E. C. (2005). Consequences of individuals' fit at work: A meta-analysis of person-job, person-organization, person-group, and person-supervisor fit. Personnel Psychology, 58(2), 281-342. doi: 10.1111/j.1744-6570.2005.00672.X

Lim, M., Ha., Y. J., Oh, D. J., \& Sohn, Y. W. (2014). Validation of the Korean version of Job Crafting Questionnaire (JCQ-K). Korean Corporation Management Review, 21(4), 181-206. Retrieved from http://kiss.kstudy.com/journal/thesis_name.asp?key=3261654

Lou, H., Luo, W., \& Strong, W. (2000). Perceived Critical Mass Effect on Groupware Acceptance. European Journal of Information Systems (EJIS), 9(2), 91-103. doi: 10.1057/palgrave.ejis.3000358

Lyons, P. (2008). The crafting of jobs and individual differences. Journal of Business Psychology, 23(1), 25-36. doi: $10.1007 / \mathrm{s} 10869-008-9080-2$

Macey, W. H., \& Schneider, B. (2008). The meaning of employee engagement. Industrial and Organizational Psychology: Perspectives on Science and Practice, 1(1), 3-30. doi: 10.1111/j.1754-9434.2007.0002.x

Nahrgang, J. D., Morgeson, F. P., \& Hofmann, D. A. (2011). Safety at work: A meta-analytic investigation of the link between job demands, job resources, burnout, engagement, and safety outcomes. Journal of Applied Psychology, 96(1), 71-94. doi: $10.1037 / \mathrm{a} 0021484$

Park, W., Kim, M. S., Jeong, S. M., \& Huh, K. M. (2007). Causes and remedies of common method bias. Korean Journal of Management, 15(1), 89-133. Retrieved from http://scholar.dkyobobook.co.kr/searchDetail.laf?barcode $=4010020608234$

Schaufeli, W. B., \& Bakker, A. B. (2004). Job demands, job resources, and their relationship with burnout and engagement: A multi-sample study. Journal of Organizational Behavior, 25(3), 293-315. doi: 10.1002/job.248

Schaufeli, W. B., Bakker, A. B., \& Salanova, M. (2006). The measurement of work engagement with a short questionnaire: A cross-national study. Educational and Psychological Measurement, 66(4), 701-716. doi: 10.1177/0013164405282471

Schaufeli, W. B., Salanova, M., Gonzalez-Roma., V., \& Bakker, A. B. (2002). The measurement of engagement and burnout: A two sample confirmatory factor analytic approach. Journal of Happiness Studies, 3(1), 71-92. doi: 10.1023/A:1015630930326

Selye, H. (1956). The stress of life. New York, NY: McGraw-Hill.

Slemp, G. R., \& Vella-Brodrick, D. A. (2013). The job crafting questionnaire: A new scale to measure the extent to which employees engage in job crafting. International Journal of Wellbeing, 3(2), 126-146. Retrieved from http://internationaljournalofwellbeing.org/index.php/ijow/article/view/217

Stöber, J. (2001). The Social Desirability Scale-17 (SDS-17): Convergent validity, discriminant validity, and relationship with age. European Journal of Psychological Assessment, 17, 222-232. doi: 10.1027//1015-5759.17.3.222

Tims, M., \& Bakker, A. B. (2010). Job crafting: Towards a new model of individual job redesign. SA Journal of Industrial Psychology, 36(2), 1-9. Retrieved from http://www.scielo.org.za/scielo.php?pid=S2071$07632010000200003 \&$ script $=$ sci_arttext\&tlng=es

Tims, M., Bakker, A. B., \& Derks, D. (2013a). The impact of job crafting on job demands, job resources, and well-being. Journal of Occupational Health Psychology, 18(2), 230-240. doi: 10.1037/a0032141

Tims, M., Bakker, A. B., Derks, D., \& Van Rhenen, W. (2013b). Job crafting at the team and individual level: Implications for work engagement and performance. Group \& Organization Management, 38, 427-454. doi: $10.1177 / 1059601113492421$ 
Topcic, M., Baum, M., \& Kabst, R. (2015). Are high-performance work practices related to individually perceived stress? A job demands-resources perspective. The International Journal of Human Resource Management, 27(1), 45-66. doi: $10.1080 / 09585192.2015 .1043136$

Van den Broeck, A., Van Ruysseveldt, J., Vanbelle, E., \& De Witte, H. (2013). The job demands-resources model: Overview and suggestions for future research. In A. B. Bakker (Ed.), Advances in Positive Organizational Psychology, 1, 83-105. doi: $10.1108 / \mathrm{S} 2046-410 \mathrm{X}(2013) 0000001007$

Van Veldhoven, M., \& Meijman, T.F. (2005). Questionnaire on the Experience and Evaluation of Work (QEEW). Preliminary JOEM, 47, English Version. Brussels: Amsterdam National Research. Retrieved from https://www.skb.nl/nl/qeew.html

Venkatesh, V., \& Davis, F. D. (2000). A theoretical extension of the technology acceptance model: Four longitudinal field studies. Management Science, 46(2), 186-204. doi: 10.1287/mnsc.46.2.186.11926

Warr, P., \& Inceoglu, I. (2012). Job engagement, job satisfaction, and contrasting associations with person-job fit. Journal of Occupational Health Psychology, 17(2), 129-138. doi: 10.1037/a0026859

Wrzesniewski, A., \& Dutton, J. E. (2001). Crafting a Job: Revisioning employees as active crafters of their work. Academy of Management Review, 26(2), 179-201. doi: 10.5465/AMR.2001.4378011

Wrzesniewski, A., LoBuglio, B., Dutton, J. E., \& Berg, J. M. (2013). Job crafting and cultivating positive meaning and identity in work. In A. B. Bakker (Ed.), Advances in Positive Organizational Psychology, 1, 281-302. doi:10.1108/S2046410X(2013)0000001015

Xanthopoulou, D., Bakker, A. B., Demerouti, E., \& Schaufeli, W. B. (2007a). The role of personal resources in the job demandsresources model. International Journal of Stress Management, 14(2), 121-141. doi: 10.1037/1072-5245.14.2.121

Xanthopoulou, D., Bakker, A. B., Dollard, M. F., Demerouti, E., Schaufeli, W. B., Taris, T. W., \& Schreurs, P. J. G. (2007b). When do job demands particularly predict burnout? The moderating role of job resources. Journal of Managerial Psychology, 22(8), 766-786. doi: 10.1108/02683940710837714

Yount, R. (2006). Research design and statistical analysis in Christian ministry, 4th Edition. Fort Worth, Texas: Southwest Baptist Theological Seminary. 